\title{
KOREAN SHAMANISM - THE RELIGION OF WOMEN
}

\author{
Kyong-geun $\mathrm{OH}$ \\ Adam Mickiewicz University \\ Institute of Linguistics, Department of Korean Studies \\ al. Niepodległości 4 \\ Poznan, Poland \\ okg615@gmail.com
}

\begin{abstract}
Shamanism is one of the oldest religions that have existed around the world. But Korean shamanism is very exceptionally in the world, because it is monopolized by women. This article focuses on the main reasons for that state of affairs. Korean shamanism has never been accepted by the ruling class as an official religion. It was not supported by the elites of the society, so it has functioned only at the margin of culture and society. Confucian-patriarchy in the Joseon dynasty (1392-1897) was one of the main reasons why Korean shamanism became the religion of women. According to Confucian ideology there must be sexual segregation in the household, and it was extended even to ritual performances for the gods. Men satisfied their religious needs through Confucianism, but they completely excluded women from it. As women were excluded from Confucian ceremonies they needed to find a religion for themselves. The gods worshiped in shamanism and the shamanistic ritual itself were treated by the ruling class as coarse and vulgar, suitable only for people of lower classes and women. The gods in Korean shamanism are not providing people with noble ideals or dreams, they just support human beings by protecting them against bad luck and bringing them good luck. A Korean shamanistic ritual consists mainly of dances and singing. Shamans communicate with their gods in a trance induced by dancing vigorously. In the Joseon dynasty dominated by Confucian ideology it was very unsuitable for men.
\end{abstract}




\section{Kyong-geun OH: Korean Shamanism - the Religion ...}

Keywords: Korean shamanism, gangsinmu, sеseupmu, shaman illness, gut (shaman rites), han, Confucian ideology, patriarchy, Korean Buddhism, Korean fundamental religion

\section{한국의 무속 - 여성들의 종교}

개요: 샤머니즘은 가장 오래된 종교들 가운데 하나이며 전세계에 걸쳐 존재한다. 그런데 한국의 샤머니즘은 세계적으로도 매우 예외적으로 여성들에 의해 점유되어 있다. 이 논문은 그러한 현상의 주요 원인들을 규명하고자 한다. 역사적으로 한국의 무속은 지배계층에 의해 단 한 번도 공식적인 종교로서 받아들여진 적이 없었다. 즉, 한국의 무속은 사회의 엘리트-지식인층으로부터 지지를 받지 못했기 때문에, 단지 주변문화로서 기능할 수밖에 없었던 것이다. 조선시대(1392-1897)의 유교적 가부장제는 한국의 무속이 여성의 종교가 되는 주원인들 중의 하나였다. 유교사상에 의하면 가사에 있어 반드시 남녀의 구별이 있어야 하는 바, 그것이 신을 위한 종교적 의례행위에까지 연장된 것이었다. 남자들은 유교의례를 통해 자신들의 종교적 욕구를 충족시키면서도 그것에서 여성들을 철저히 배제하였다. 여성들이 유교적 의례에서 배제됨에 따라 결국 그들은 자신들만의 종교의례를 찾지 않을 수 없었다. 남성 지배계급은 무속에서 섬겨지는 신들과 무속의례를 저속하고 조잡한 것들로서 오로지 하층민 혹은 여성들을 위한 것이라 여겼다. 한국무속의 신들은 인간에게 깊은 사상 혹은 고매한 가르침을 주는 존재가 아니라, 단지 불행을 막고 복을 가져다 줌으로써 그들의 삶을 안전하게 보호하고 도와주는 존재들이다. 한국의 무속의례는 주로 춤과 노래로 구성되어 있다. 무당은 격렬한 춤을 통한 무아지경에서 신과 교통하는 것이다. 하지만 유교사상이 지배하는 조선시대에 그러한 것은 남성들에게 받아들여질 수 없는 것이었다.

키워드: 한국무속, 강신무, 세습무, 신병(神病), 굿, 한(恨), 유교사상, 가부장제, 한국불교, 한국근본종교

\section{KOREAŃSKI SZAMANIZM - RELIGIA KOBIET}

Abstrakt : Szamanizm jest jedną z najstarszych religii i istnieje niemal na całym świecie. Koreański szamanizm wykazuje jednak pewne cechy szczególne odróżniające go od innych form tego zjawiska na świecie, gdyż jest zmonopolizowany przez kobiety. W artykule zostaną przedstawione główne przyczyny tego faktu. Koreański szamanizm nigdy nie został zaakceptowany przez klasę rządzącą jako oficjalna religia, nie był także popierany przez elitę społeczeństwa i w związku z tym musiał funkcjonować jedynie na marginesie kultury koreańskiej. Konfucjański patriarchat w czasie dynastii Joseon (1392-1897) istotnie przyczynił się do tego, że koreański szamanizm został religią kobiet. Według ideologii konfucjańskiej, w sprawach rodzinnych należy dokonywać segregacji płciowej, która została rozszerzona nawet na sferę rytuałów religijnych. Mężczyźni zaspokajali swoje potrzeby religijne praktykując konfucjanizm, ale całkowicie wykluczyli z niego kobiety. Skoro zaś kobiety zostały wykluczone z 
rytuałów konfucjańskich, musiały znaleźć jakąś religię dla siebie. Bogowie czczeni w koreańskim szamanizmie oraz sam rytuał szamański były bowiem traktowane przez klasę rządzącą jako trywialne, wręcz wulgarne i nadające się jedynie dla ludzi klas niższych i kobiet. Bogowie szamanizmu koreańskiego nie są istotami dostarczającymi ludziom szlachetnych ideałów lub marzeń a jedynie pomagają im w życiu codziennym chroniąc przed nieszczęściami i gwarantując szczęście. Koreański rytuał szamański składa się głównie z tańców i śpiewu. Szamani komunikują się z bogami-patronami w transie osiągniętym poprzez energiczne i energetyczne tańce. Należy jednak pamiętać, że w zdominowanym przez ideologię konfucjańską okresie panowania dynastii Joseon takie zachowanie było postrzegane jako bardzo nieodpowiednie dla mężczyzn.

Słowa kluczowe : koreański szamanizm, gansinmu, seseupmu, choroba szamańska, gut (szamański rytuał), ideologia szamańska, patriarchat, koreański buddyzm, koreańska religia fundamentalna

\section{Shamanism in Korea}

Shamanism understands the world not through any natural phenomena, which could be explained scientifically, but believes that the supernatural power controls the world. Such shamanistic thinking captivated the hearts of Koreans for thousands of years. Therefore their social lives strictly follow Confucian values, but still their mentality is still deeply rooted in shamanistic ideas of the world. The system of thought/philosophy of the Koreans was seriously influenced by Buddhism during the Goryeo dynasty (918-1392), by Confucianism during the Joseon dynasty (1392-1910), and in modern society by rational and scientific thinking. But the shamanistic way of thinking did not disappear, it just deeply permeated to their minds and still exerts influence on their lives (Lee Gyu-tae 2000: 5) Therefore Korea is one of the places where shamanism has been clearly preserved until today. It may be that the main reason for the continued existence of shamanism in Korean society is due to the sincere desires of the people, especially those who are suffering from poverty and anxiety. Throughout their long history in Korea, shamans have had a role as entertainers for the people in addition to their religious functions (An introduction to Korean culture 2004:126, 133). It was also possible due to the fact that 
in Korean traditional society there was no monotheistic religion. As one knows well, a monotheistic religion does not tolerate any other religions.

Korean shamanism was not like the other universal religions and did not have any fixed religious dogma, generalised scriptures, unified organisation of priests, but as a natural religion could for a long time spread deep roots in the people's daily life. People naturally avoid misfortune and pursue happiness in their life. Shamanism performs a very practical function in a man's life as a religion, which provides him with peace and happiness in this world, not with the redemption of a soul or the life after death. Traditionally Koreans were very practical in their religious life. Therefore one may say that the very practical aspect of Korean shamanism is one of the main reasons for its continual influence on Korean contemporary society in spite of the great changes in it. Koreans frequently perceive every religion through fortune or misfortune, which may be brought upon them by it. That is the typical phenomenon in their religious life that is deeply influenced by shamanic concepts. Because shamanism concentrates mainly on how I or my family can earn a material profit/benefit in this world by paying tribute to gods rather than on emphasis on universal virtues such as love, mercy, wisdom, justice, transcendence, freedom, immortality etc (Choi Jun-sik 2009: 179).

It should be stressed here that shamanism is the fundamental religion of Koreans and the core of their traditional culture. But for most Koreans shamanism is just a primitive superstition, and they treat it with disdain. That is because of Confucian ideology in the past and European education in modern times. The Korean government has tried to do away with shamanism through the modernisation of Korean society in the 1960s and 1970s, but shamanism did not vanish at all, it is rather flourishing in the contemporary society adapting itself to new circumstances. Only its form has changed. 


\section{Korean shamans}

The Korean shamanism may be divided into 1) the northern type and 2) the southern type. Gangshinmu is the shaman of the northern type, which means a possessed shaman. It is characterised by ecstasy, different costumes, singing, and dancing in the ritual service. Not everyone may become a gangshinmu, because the most important qualification for the shaman is experiencing the so-called 'shaman illness'. They are mystical and act individually.

The 'Shaman illness' is a 'pathological phenomenon' given as a sign by a god/spirit who wants somebody to be his shaman (Choi Gilseong 1999: 363-364). A person shall suffer from an unknown illness with bodily pain and mental exhaustion. They will often dream of demons or gods, and they will experience hallucinations and illusions even during the day. They may take a variety of medications, but there is nothing that makes them feel better. Consequently, a person goes to a shaman who knows about "shaman illness". The illness may be overcome only when a haunted person accepts the spirit and becomes a shaman. From that moment that person will have supernatural power and can act as a medium between a human and spirits.

The southern type is seseupmu, which means a shaman by succession, who does not fall into the ecstasy during the shamanic ritual. This is a profession so any person can become a sеsеupmu, although it is usually practiced by women. As a rule, a mother-in-law teaches her daughter-in-law how to conduct and perform ceremonies and rituals. They are strictly connected with people of a village where they work (like as a parish priest). They are rather artistic or ceremonial and work in a group.

Gangshinmu as a private being/independent shaman works freely everywhere, but sеsеuрти can work only in his/her district. So with the collapse of the traditional society seseupmu is in progressive decline, but gangshinmu is becoming more prevalent with the growth of urbanisation and individualisation (Choi Gil-seong 1999: 365). 


\section{Shamanistic rite $g u t$}

The structure of Korean shamanism consists of god, shaman (priest), and believer, so there is no difference from any other monotheistic religions (Choi Jun-sik 2009: 23). It means that the main purpose of shamanism is receiving help from god by the shaman's mediation between men and god. A believer can communicate with gods only through the shaman. One can say that in this case a shaman is the same as a Catholic priest.

The most important function of the shaman is the performance of rituals to help people solve their problems, which they cannot solve by themselves. According to shamanism all misfortunes and sorrows suffered by a human being are caused by angry gods or the souls of dead people (Yun I-heum et al. 2001: 85), therefore the ritual service is performed for pacifying a deceased spirit through a shaman in order to achieve harmony and reconciliation between people and spirits.

Korean shamanism is very similar to animism, because in Korean shamanism people worship all the things in the world giving them contact with divinity (Choi Jun-sik 2009: 79-80). In Korean shamanism even an unimportant soul/spirit is not ignored. It was said that if they were treated inappropriately they would bear resentment/regrets and do harm to people, so Koreans were always trying to be good to them in order to they would not have any resentments. But in Korean shamanism there are many gods with resentment, and if their resentment/grudge is greater they are treated as a more powerful god. That is one of the specific characters of Korean shamanism. According to shamans in the world of mortals there are many problems because of the resentment of the souls of the deceased and spirits. For that reason a shaman performs gut in order to satisfy their grudge through the communication between them and people (Choi Jun-sik 2009: 82). However, the main purpose of shamanistic ritual performance is the expulsion of misfortune and the calling for happiness that is good fortune, health, wealth, and longevity for family members. Those four are the most highly valued things in life for 
Korean people (An introduction to Korean culture 2004: 133). Here one can see the pragmatism of Koreans in their religious life.

Gut is a very complicated and elaborately organised ritual, so a shaman must learn a lot about it in order to perform it properly. Generally it take them about ten years (Choi Jun-sik 2009: 38). It is significant evidence that Korean shamanism is a pure religion, which, in its own way, is well organised and has a long tradition. In general, there are twelve stages in the shamanic ritual. At each stage, the shaman wears different clothes in various colours and forms, which may include official dresses, a military uniform, a monk's costume etc.

But gut comprises three main stages:

1. inviting a god to attend the ritual,

2. entertaining the god to make him/her happy and willing to help (give advice how to solve a problem),

3. sending the god back to the other world (Choi Gil-seong, 1996: 131-133).

During this ritual a female shaman dances and sings all the time - the Korean drum is the most important instrument here. She experiences ecstasy by dancing vigorously. When in trance she hears the words uttered by a god, and then she passes the message to her clients. That is the most important element of gut ceremony.

Confucianism could not be fit for/be capable of carrying out the matters connected with death, which is the biggest fear for men, because it had a very weak religious function. It did not approve of the life after death, so it could offer/provide only ancestral memorial services to the issues/matters of death. Therefore during the Joseon dynasty when parents, for example, lost their beloved child they could only perform the shamanistic ritual gut to comfort themselves in their sorrow. (Choi Jun-sik 2009: 121). For that reason taking care of the marginalised and ignored people in society was the duty/assignment of shamanism. Especially women who were excluded by the ruling class and men could do for themselves only one kind of religious ceremony, and it was gut. Confucian ritual for the souls of ancestors is absolutely masculine/manly, but gut is all composed of women. Both shaman and believers are all women. Men are there just as the musicians or helpers. In a word, gut was for women and was a space of liberation of women 
(Choi Jun-sik 2009: 119).

Consequently due to women, Korean shamanism could survive during the Joseon dynasty despite all kinds of oppression.

\section{How did Korean shamanism become the religion of women?}

As has been mentioned above Korean shamanism is almost monopolised by women. In general shamans are women who perform all the rituals. It is not a feature of shamanism in general, but only of Korean shamanism (Choi Gil-seong 1996: 68). Of course there were other reasons for that, but first of all in Korea shamanism was rejected by the ruling class, by people who had power in the state. When Confucianism and Buddhism were adopted by Korea from China (about the $3-4^{\text {th }}$ century) the ruling class gave up shamanism and it started to function at the margin of culture. In a word, Korean shamanism was not supported by the social elites for over 1600 years and that is why it had no chance to develop into a higher culture (Yun I-heum et al. 2001: 118).

It is known that in human history religions could be accepted and supported by the ruling class when they were helpful for them in the reinforcement of their political power. In that case the monotheistic religions were most effective, because there must be only one God in heaven, and only one ruler on earth. The ruler justified his political power on earth as a representative of the God. As a result these religions were able to develop into global high/universal religions through the compromise with political powers. It means that they must fulfil/perform a function in a society as a political ideology. But if a religion could not do or was not fit for that, it could not grow or might even die out. For that reason even Buddha at the end also had to become a God to his believers. Originally Buddhism was a religion of own efforts/self-reliance and Buddha taught people to judge all things only 
by their own rational judgment. But because of his believers he became a God, the same as in other religions, except for the positions of the Creator or the last arbiter. Now in Korea Buddha is no longer the "Enlightened One" or a great teacher/master for his believers, but he is just a great spirit/deity. For the ordinary/common believers Buddhism is just a religion, which helps them in realising/fulfilling their wishes (Choi Jun-sik 2009: 159-163). But Korean shamanism is not a religion, which in collusion with the political authority takes control of men. On the contrary it serves men. In other words, in Korean shamanism men are not for gods but gods are for men, therefore it could not be useful for reinforcement of political power, and consequently was rejected by the ruling class. However one may say that Korean shamanism is a very humane religion, because it is not related to any political power and just reacts mostly to the emotions and desires of people.

Confucianism was the most exclusive teaching among the Asian teachings. Additionally it did not approve of the supernatural power or the spirits/ghosts. So it was a fatal blow to shamanism. The teachings of Confucianism strongly emphasised rationality. But shamanism was far from rationality and furthermore women played a central role in its rite. Therefore for the Confucian scholars shamanism was just a vulgar thing, and they wanted to be rid of it as quickly as possible (Choi Jun-sik 2009: 109-110). Consequently the shamans and also Buddhist monks were degraded to the lowest class, and for them entry to the castle town/capital city was banned. Thus shamanism became a religion for the lower class, especially for women.

In Korean traditional society the status of men was higher than the status of women and the image of women was rather negative, so if in Korea there was any sexual discrimination it was because of the Confucian-patriarchy in the Joseon dynasty (1392-1897). According to Confucian ideology there must be sexual segregation in the household, and it extended even to ritual performances for the gods. Traditionally, appeasing domestic gods was primarily a housewife's responsibility, so men engaged in ancestor worship according to Confucianism, but never concerned themselves with the house gods (An introduction to Korean culture 2004: 123). The gods worshiped in shamanism and the shamanistic ritual itself were treated by Confucian scholars as coarse 
and vulgar things, only for the people of lower class and women, because gods in Korean shamanism are not beings providing people with noble ideals or dreams. They just support and protect the life of a human being by protecting people against bad luck and bringing them good luck.

Very often the Koreans considered that women were more inclined to shamanism than men, because their educational level was lower than that of men. So they were confident that if women were educated they would forsake shamanism. To some degree it was reasonable as in the past for a long time women did not have any chance of an education, and most intellectuals were men with a Confucian education. However one should understand here that women are more dependent on religions regardless of their educational level, because they are naturally more religious than men (Choi Gil-seong 1996: 6869). Essentially the religious beliefs are not based on rational thinking. It is not only true for women but also applies to men. The diffusion/spread of education may make men less religious, but it is possible only to a certain extent. It means that, faith/religious belief is not a thing, which is inversely proportional to knowledge or education.

In the Confucian society of the Joseon Dynasty there was no room for women and their religious activities. Men satisfied their religious needs through Confucianism, but they completely excluded women from it. Moreover, Confucianism focuses strongly on rationality, so it was unable to give any answers to abstract matters, especially about the life after death. As women were excluded in Confucian ceremonies they needed to find a religion for themselves. Besides Confucianism there was also Buddhism in Korea, but as is known Buddhism is a self-reliant religion, so it was too difficult for uneducated people and women. Besides, Korean shamanism not only does not discriminate against women, but it worships minor gods including many goddesses rather than almighty male-gods, and gives people the mostly earthly fortunes such as wealth and health etc. Consequently women could satisfy their religious needs only through shamanism. In a word, it was the only belief the women could rely on. And the only ritual service they could perform to ease their grief for 
their lost family members was the shamanic ritual gut.

Gut was the only occasion where the women of the Joseon Dynasty could express their feelings without any restrictions, so it was for them the only means of liberation. Moreover, shamanism was the belief providing for the people of lower class and seeks only good fortune of individuals, so it could not include complicated and difficult religious or philosophical ideologies. Instead of them, Korean shamanism developed to the utmost its elements, which the people could understand sensuously like songs, dances and the mechanism of wish fulfilment etc. The shamanistic ritual gut consist of songs and dances from the beginning to the end. But they are not just for amusement. They are the religious means to achieve communication with gods, because Korean shamans communicate with their gods in a trance that occurs or is achieved through songs and dances (Choi Junsik 2009: 136). They do not use any other artificial means such as alcohol or hallucinogenic substances. Nevertheless, in the Joseon dynasty dominated by Confucian ideology the structure of shamanistic ritual considered was very unsuitable for men.

Anyway here one should remember that Korean shamanism symbolises the greatness of Korean culture, because it tolerated a religion only for women in the period of pre-modern society. However, unfortunately it was not a religion, which was acceptable to or suitable for a modern society.

\section{Conclusion}

The main reason why Korean shamanism became the religion of women was because of the Confucian-patriarchy during the Joseon dynasty (1392-1897). Korean shamanism did not have any fixed religious dogma/doctrine, generalised scriptures, unified organisation of priests, universal virtues, and profound philosophical ideologies, so it could not be supported by the ruling class. Furthermore its ritual 
consists mainly of dances and singing.

During the Joseon dynasty Confucianism despised shamanism as a superstition and tried to do away with it, but it was rather a kind of a religious suppression and also was not a proof of the superiority of education to religious belief. Nevertheless in the period of modernisation the Korean government pursued the policy of abolishing superstition. It has been an on-going process from the time of enlightenment and the Japanese colonial period. But shamanism did not fade away from Korean society. It did not disappear, only has changed its form to adapt to modern society. Now there are about ten thousand Protestant ministers, the most numerous denomination among the clergy of the universal religions in Korea, but there are about twenty to thirty- thousand shamans (Choi Jun-sik 2009: 126).

The foreign/imported religions, Buddhism, Catholicism, Protestantism etc., strove to assimilate Korean shamanism, but the result was rather the reverse. Especially in Korean Protestantism there are many elements from shamanism. Seemingly Korean shamanism does not present any resistance to foreign religions, but it changes their teachings to fit within its own frame (Jang Nam-hyeok 2002: 12-13). The Korean people at the crisis and the fall of their nation, especially during the Japanese colonialism (1910-1945), accepted Christianity, but it was not the result of their good or thorough understanding of Christian doctrine. For them Christianity was rather a symbol of Western culture, which was considered better than the values of Korean traditional culture, and they felt the sense of security as if they had gained a strong guardian for themselves in churches, which were managed by the Western missionaries who enjoyed privileges of extraterritoriality (Lee Gyu-tae 2000: 10-11). Therefore it is advisable to regard shamanism from the religious point of view, not from the political or educational policy.

Korean shamanism is significant as a specifically Korean religious phenomenon that is monopolised by women. It is a very indigenous component of Korean religion and culture, thus it is also a precious cultural heritage of the Korean nation. Except for the culture of the social elite, the substantially greater part of Korean traditional 
culture is rooted in shamanism (Choi Jun-sik 2009: 20). Thus shamanism is the essence of Korean art, culture, and even religion. Folk music, songs, dances, clothes, drama (pansori) include the many elements of shamanism.

However in the contemporary society there is no chance for Korean shamanism to develop as a religion, because for over a century the Koreans have looked at their traditional culture as well as shamanism through the eyes of foreigners. Koreans know almost nothing about shamanism and shamanic rituals, treat it with disdain and regard it as a primitive superstition. But now Koreans should openly admit that shamanism is a part of their culture and their religion. They should also develop its positive features.

\section{References}

Choi Gil-seong (최길성). 1978. 『한국 무속의 연구』 [A study on Korean shamanism]. Seoul: Asea Munhwasa.

Choi Gil-seong (최길성). 1996. "한국인의 한』[Han of Koreans]. Seoul: Yejeonsa.

Choi Gil-seong (최길성). 1999.「샤머니즘의 비교」[A comparison of shamanisms]. 『비교민속학과 비교문화』[Comparative Folklore and Cross-culture] Choi In-hak et al. Seoul: Minsokwon.

Choi Jun-sik (최준식). 2007. Buddism - Religion in Korea. Seoul: Ewha Woman's University Press.

Choi Jun-sik (최준식). 2009. 『무교 - 권력에 밀린 한국인의 근본신앙』[Shamanism - the fundamental beliefs of Koreans rejected by political power]. Seoul: Mosineun-saramdeul.

Choi Sang-chin (최상진), Kim Ui-chol (김의철). 1992. Conceptual and Empirical Analyses of Han: An Indigenous Form of Lamentation. Hawaii: University of Hawaii.

Eliade Mircea. 1994. Szamanizm $i$ archaiczne techniki ekstazy. Warszawa: Wydawnictwo Naukowe PWN. 
Kyong-geun OH: Korean Shamanism - the Religion ...

Geum Jang-tae (금장태). 2009. 『귀신과 제사 - 유교의 종교적 세계』 [Spirits and ancestral rites - the religious world of Confucianism]. Seoul: J\&C.

Hogarth Hyun-key Kim. 2002. Syncretism of Buddhism and Shamanism in Korea. Seoul: Jimoondang.

Hwang Rushi. 2000. 『우리 무당 이야기』 [A story of our shamans]. Seoul: Daewansa.

Jang Nam-hyeok (장남혁). 2002. 『교회 속의 샤머니즘 - 한국 샤머니즘에 대한 기독교적 조명』 [Shamanism in churches $-a$ Christian view of Korean shamanism]. Seoul: Jimmoondang.

John H. Koo and Andrew C. Nahm (eds.). 2004. An introduction to Korean culture. Seoul: Hollym.

Kim Harvey Youngsook. 1979. Six Korean women: The socialization of Shamans. St. Paul: West Publishing Co.

Kim Mi-yeong (김미영). 2010. 『유교의례의 전통과 상징』

[Tradition and meanings of Confucian rites]. Seoul: Minsokwon.

Kim Tae-gon (김태곤). 1998. Korean Shamanism - Musism. Seoul: Jimoondang.

Kim Tae-gon (김태곤). 1991. 『한국의 무속』 [Korean shamanism]. Seoul: Daewansa.

Kim Yeol-gyu (김열규) et al. 2001. 『한국인의 죽음과 삶』

[Death and life of Koreans]. Seoul: Cheolhak-kwa hyeonsilsa.

Lee Chan-su (이찬수). 2009. 『한국 그리스도교 비평: 그리스도교, 한국적이기 위하여』 [A criticism of Korean Christianity: Christianity, to be Korean]. Seoul: Ihwa Women's University.

Lee Eun-bong (이은봉). 2000. 『한국인의 죽음관』 [The Korean view of death]. Seoul: Seoul Natioanal University.

Lee Gyu-tae (이규태). 2000. 『한국인의 샤머니즘』] [Shamanism of Koreans]. Seoul: Sinwon-munhwasa.

Lee Kyeong-won (이경원). 2011. 『한국인의 종교사상 - 궁극적 실재의 제문제』 [Religious thoughts of Koreans-problems of ultimate existence]. Seoul: Munsacheol.

Lee Kyeong-yeop (이경엽). 2004. 『씻김굿 - 삶의 끝자락에서 펼치는 축제』[Ssit-kim gut - the festival performing at the 
end of life]. Gwangju: Haneol Media.

Lee Sang-mok (이상목) et al. 2005. 『한국인의 죽음관과 생명윤리』 [View of death and life ethics of Koreans]. Wydawnictwo Sejong.

Lee Young-shik (이영식). 2004. Shaman Ritual Music in Korea. Seoul: Jimoondang Publishing Company.

Ryu Dae-yeong (류대영). 2009. 『한국 근현대사와 기독교』 [Korean modern and contemporary history and Christianity]. Seoul: Pureun-yeoksa.

Ryu Seung-kuk (류승국). 2008. 『한국유학사』 [A history of Korean Confucianism]. Seoul: Institute of Eastern Asia, Seonggyunkwan University.

Yun I-heum (윤이흠) et al. 2001. "한국인의 종교관 - 한국정신의 맥락과 내용』 [Religious views of Koreans - context and content of the Korean spirit]. Seoul: Seolu National University. 